\title{
The significance of Southwest Greenland as winter quarters for seabirds
}

\author{
DAVID BOERTMANN, PETER LYNGS, FLEMMING RAVN MERKEL and \\ ANDERS MOSBECH
}

\section{Summary}

The coastal and offshore waters of Southwest Greenland are internationally important winter quarters for seabirds. We crudely estimate a minimum of 3.5 million seabirds using the region in winter, mainly from Arctic Canada, Greenland and Svalbard, with smaller numbers also from Alaska, Iceland, mainland Norway and Russia. The most numerous species are Common Eider Somateria mollissima, King Eider S. spectabilis, Brünnich's Guillemot Uria lomvia and Little Auk Alle alle. The most immediate threat to the seabirds in Southwest Greenland is hunting, and current levels of usage of the Greenland breeding populations of Brünnich's Guillemot and Common Eider are considered unsustainable. Conservation measures are required for these populations.

\section{Introduction}

The sea off Southwest Greenland (Figure 1) is biologically highly productive and during summer supports high biodiversity including many seabirds (Born and Böcher 2001). However, in winter these waters are used by abundant seabirds that breed around the North Atlantic (Salomonsen 1950, 1979b, Brown and Nettleship 1981, Boertmann 1994). Lack of quantitative data on the seabird populations may explain why the conservation importance of South-west Greenland has not generally been recognized in an international context. For example, the region was not included in the recent Ecoregion Conservation initiative by the World Wide Fund for Nature (Martin-Jones and O'Connor 1999), although it seems comparable in importance to Ecoregions designated in other parts of the North Atlantic.

Since 1996, the results from six aerial surveys and one ship-based survey of seabirds carried out in Southwest Greenland waters during the winter have been analysed and published (see below). The aim of this paper is therefore to review the importance of Southwest Greenland for wintering seabirds.

\section{Seabird data}

Seven seabird surveys were conducted in late winter (when light conditions are favourable) between 1981 and 1999, covering the coastal and offshore areas between $60^{\circ}$ and $71^{\circ} \mathrm{N}$ (Table 1 and Figure 2). The first six of these surveys were aimed mainly at offshore areas, while the 1999 survey specifically covered the 


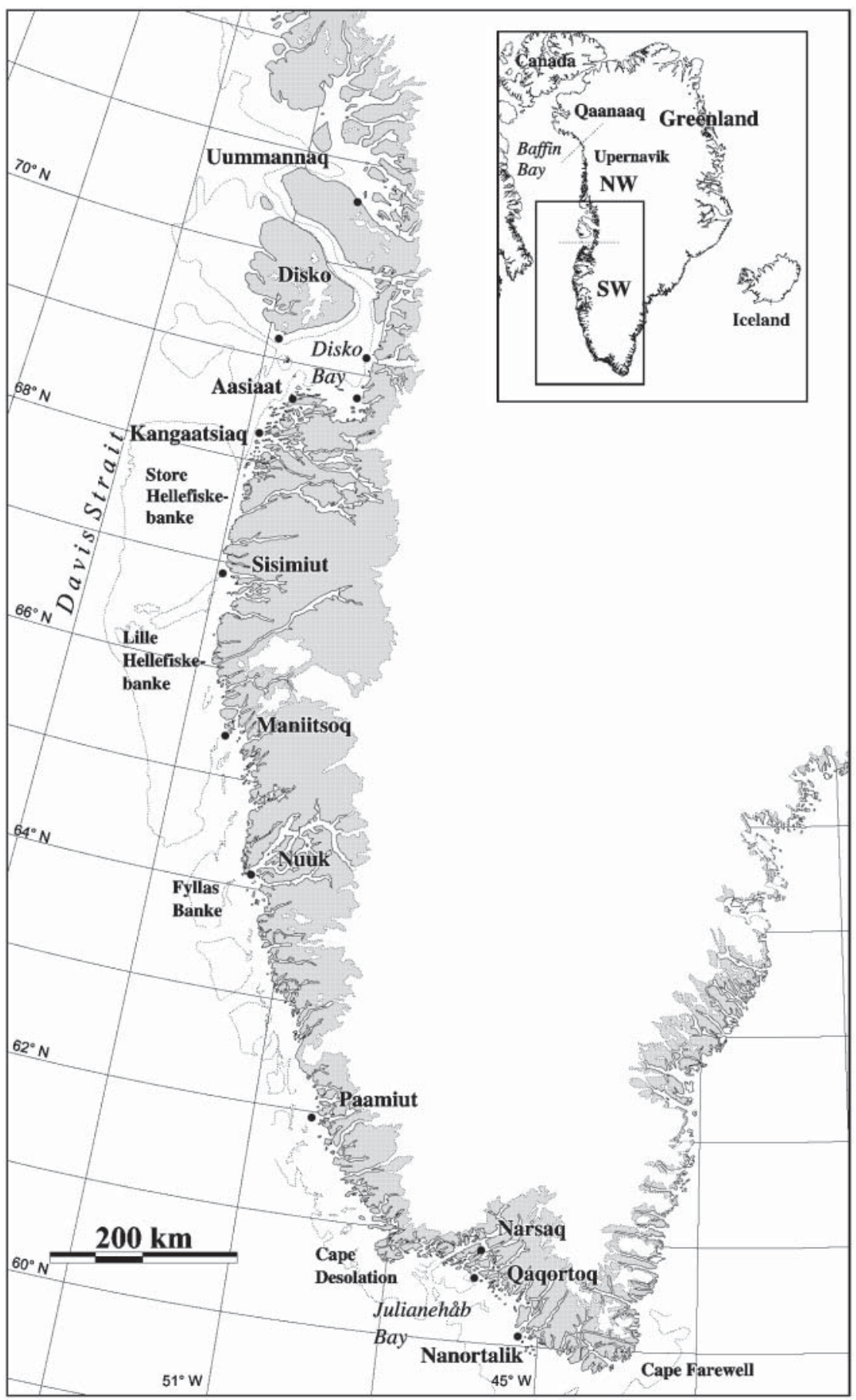

Figure 1. Map of the Southwest Greenland Region, with major site names and towns shown. Dotted lines are the $200 \mathrm{~m}$ isobath. Hatched lines on the overview map indicate borders between Greenland regions: Qaanaaq to the north, Northwest Greenland, Southwest Greenland and Southeast Greenland. Dots indicate towns. 
Table 1. Seabird surveys covering Southwest Greenland waters in winter (November through March).

\begin{tabular}{|c|c|c|c|c|}
\hline Year & Period & Platform & Effort $(\mathrm{km})$ & Source \\
\hline 1981 & March & Aeroplane & approx. $8,500^{a}$ & $\begin{array}{l}\text { Mosbech and Johnson (1999), } \\
\text { Koski and Davis (1994) }\end{array}$ \\
\hline 1982 & March & Aeroplane & approx. $10,000^{a}$ & $\begin{array}{l}\text { Mosbech and Johnson (1999), } \\
\text { Koski and Davis (1994) }\end{array}$ \\
\hline 1989 & Feb./March & Ship & 1,022 & Durinck and Falk (1996) \\
\hline 1991 & March & Aeroplane & 2,868 & $\begin{array}{l}\text { Mosbech and Johnson (1999) } \\
\text { Heide-Jørgensen and Reeves (1996) }\end{array}$ \\
\hline 1993 & March & Aeroplane & 3,222 & $\begin{array}{l}\text { Mosbech and Johnson (1999), } \\
\text { Heide-Jørgensen and Reeves (1996) }\end{array}$ \\
\hline 1998 & March/April & Aeroplane & 4,834 & Heide-Jørgensen et al. (1999) \\
\hline 1999 & Feb./March & Aeroplane & 4,661 & Merkel et al. (2002) \\
\hline
\end{tabular}

ancluding transects flown on the Canadian side of Davis Strait and Baffin Bay.

coastal archipelagos. The aerial surveys were carried out mainly as transect flights, but in 1999 some fjords and coastal areas were surveyed by total counts (for details see Merkel et al. 2002). In 1981 and 1982, DeHavilland Twin Otter aircraft were used, flying at a ground speed of $200-240 \mathrm{~km} / \mathrm{h}$ and an altitude of 150 m. In 1991-1999 a Partenavia P-68 Observer was the observation platform, flying at $150-200 \mathrm{~km} / \mathrm{h}$ and an altitude of $85 \mathrm{~m}$ or up to $230 \mathrm{~m}$ when marine mammals also were included as subjects of the surveys (for details see Mosbech and Johnson 1999 and Merkel et al. 2002). The ship-based survey in 1989 was carried out from fisheries inspection vessels and passenger vessels, applying international observation standards (Tasker et al. 1984).

Flyway relationships of the wintering seabirds were derived from a detailed analysis of the bird-ring recovery material kept in the Zoological Museum of Copenhagen (ZMUC; Lyngs 2003). An official bag-record registration system introduced in 1993 includes the most important of the bird species hunted in Greenland (Table 2) and annual bag-records are published by the Greenland Homerule (Namminersornerullutik Oqartussat 2002). More detailed hunting statistics from 1994 to 1999 were provided by the Greenland Directorate of Industry. Species such as Mallard Anas platyrhynchos, King Eider Somateria spectabilis and Harlequin Duck Histrionicus histrionicus occur in Greenland at least in winter on the sea and are in the present context included as seabirds. The winter period is here defined as November to March inclusive.

\section{Study area}

The study region comprises the shelf and nearshore waters off Southwest Greenland, between Nanortalik at about $60^{\circ} \mathrm{N}$ and Disko Bay at $69^{\circ} \mathrm{N}$ (Figure 1). Although it is generally considered to lie within the Arctic region, particular oceanographic and climatic conditions keep large parts of the sea area off Southwest Greenland essentially free of ice during the winter. Thus, it has been characterized as a polynya (an area of recurrent open water surrounded by sea ice), although it is open to the south (Brown and Nettleship 1981).

The coastal areas of Southwest Greenland have a typical oceanic climate with a low annual temperature amplitude: mild winters alternating with cool 

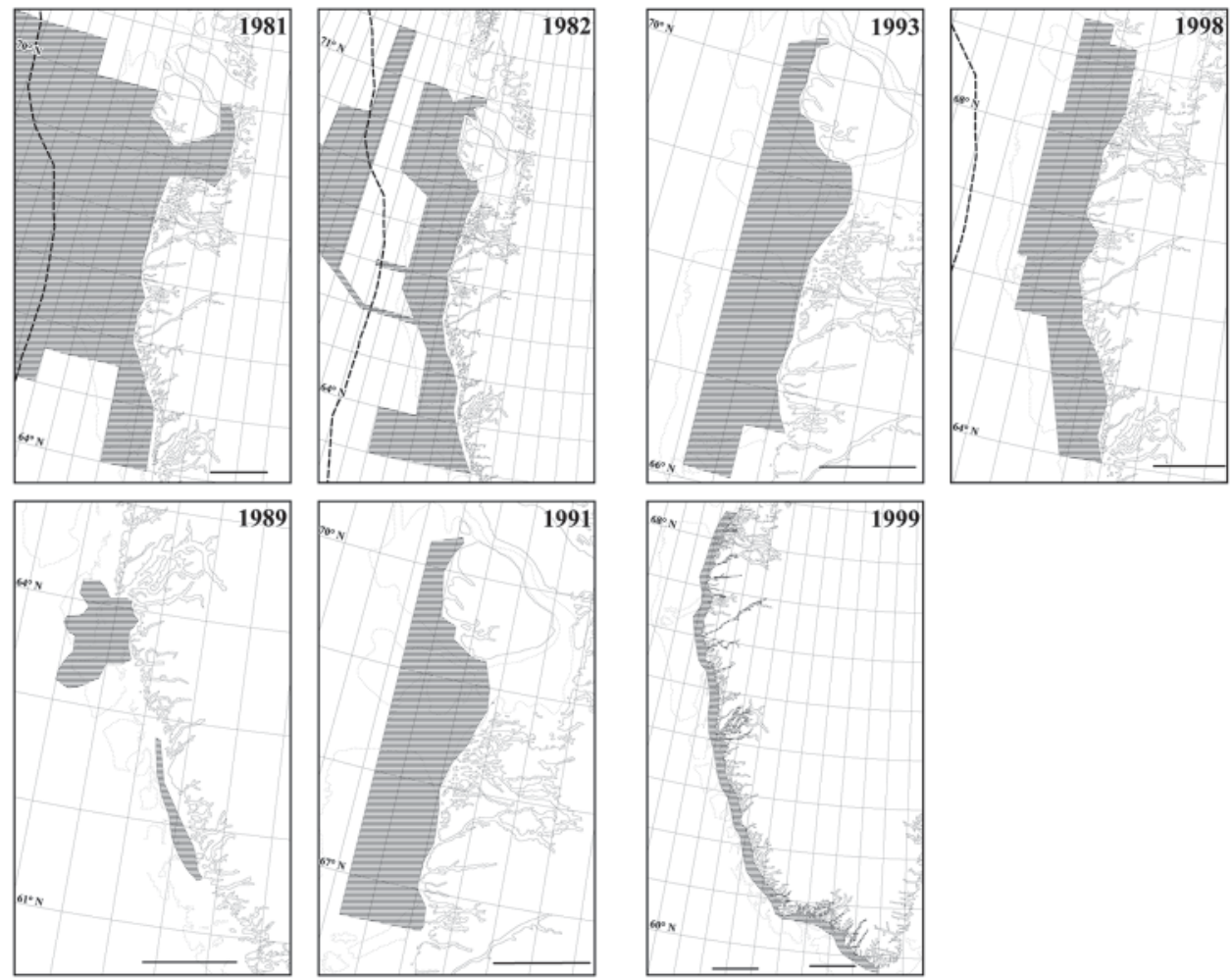

Figure 2. The areas covered (grey shading) by the winter seabird surveys in Southwest Greenland. The 1989 survey was ship-based; all others were aerial. Hatched line is the border with Canada, dotted lines are the $200 \mathrm{~m}$ isobath and the scale bar in lower right corner equates to $100 \mathrm{~km}$. For sources see Table 1.

summers. Mean July temperature is less than $10^{\circ} \mathrm{C}$ throughout the region, while mean February temperature is about $-5^{\circ} \mathrm{C}$ in the southern part and about $-12^{\circ} \mathrm{C}$ in the northern part.

The waters between $63^{\circ}$ and $65^{\circ} \mathrm{N}$ are more or less free of winter ice, due to an influx of relatively warm Atlantic water: the Irminger Current. This water mixes with cold Arctic surface water from the East Greenland Current to form the West Greenland Current (Mosbech et al. 200o). Wind also removes ice from the coast. During very cold spells late in the winter (January-March) drift-ice enters from the west or is formed locally and may cover much of the region (Valeur et al. 1997, Mosbech et al. 2000). Ice is a prominent feature in the winter, both to the north and the south. South of $63^{\circ} \mathrm{N}$, multi-year drift-ice from the East Greenland Current often enters from the south. This ice may arrive late in the winter, spring or even early summer and rarely reaches as far north as $64^{\circ} \mathrm{N}$ (Valeur et al. 1997).

North of $65^{\circ} \mathrm{N}$, drift-ice usually covers the sea in the period from January to May. However, wind and tidal currents form a narrow ice-free lead system between the drift-ice and the outer coast (Figure 3), sometimes as far north as Disko Island (Valeur et al. 1997). A significant open-water area is always present 
Table 2. Seabirds occurring in Southwest Greenland in winter, their closed hunting season (in Southwest Greenland only) according to old (Grønlands Hjemmestyre 1989) and new (Grønlands Hjemmestyre 2004) regulations and bag-record statistics (Namminersornerullutik Oqartussat 2002).

\begin{tabular}{|c|c|c|c|c|}
\hline \multirow[t]{2}{*}{ Species } & \multicolumn{2}{|l|}{ Closed season } & \multirow{2}{*}{$\begin{array}{l}\text { Highest } \\
\text { annual } \\
\text { bag record } \\
\text { 1994-2000 }\end{array}$} & \multirow{2}{*}{$\begin{array}{l}\text { Part taken } \\
\text { in SW } \\
\text { Greenland } \\
\text { Nov.-Mar. } \\
(\%)\end{array}$} \\
\hline & Old & New & & \\
\hline $\begin{array}{l}\text { Northern Fulmar } \\
\text { Fulmarus glacialis }\end{array}$ & I June-15 Aug. & 1 June-31 Aug. & n.r. & $\mathrm{u}$. \\
\hline $\begin{array}{l}\text { Great Cormorant } \\
\text { Phalacrocorax carbo }\end{array}$ & 1 Apr.-30 Sept. & 1 Apr.-3o Aug. & n.r. & $\mathrm{u}$. \\
\hline $\begin{array}{l}\text { Mallard } \\
\text { Anas platyrhynchos }\end{array}$ & 1 June-15 Aug. & 16 Mar.-31 Aug. & n.r. & $\mathrm{u}$. \\
\hline $\begin{array}{l}\text { Common Eider } \\
\text { Somateria mollissima }\end{array}$ & I June-3o Sept. & 1 Mar.-14 Oct. & 83,810 & 53 \\
\hline $\begin{array}{l}\text { King Eider } \\
\text { Somateria spectabilis }\end{array}$ & I June-3o Sept. & 1 Mar.-14 Oct. & 5,557 & 47 \\
\hline $\begin{array}{l}\text { Harlequin Duck } \\
\text { Histrionicus histrionicus }\end{array}$ & Fully protected & Fully protected & - & - \\
\hline $\begin{array}{l}\text { Long-tailed Duck } \\
\text { Clangula hyemalis }\end{array}$ & 1 June-15 Aug. & 1 Mar.-31 Aug. & n.r. & $\mathrm{u}$. \\
\hline $\begin{array}{l}\text { Red-breasted Merganser } \\
\text { Mergus serrator }\end{array}$ & 1 June-15 Aug. & Fully protected & n.r. & $\mathrm{u}$ \\
\hline $\begin{array}{l}\text { White-tailed Eagle } \\
\text { Haliaeetus albicilla }\end{array}$ & Fully protected & Fully protected & - & - \\
\hline $\begin{array}{l}\text { Purple Sandpiper } \\
\text { Calidris maritima }\end{array}$ & Fully protected & Fully protected & - & - \\
\hline $\begin{array}{l}\text { Iceland Gull } \\
\text { Larus glaucoides }\end{array}$ & 1 June-15 Aug. & 1 May-31 Aug. & n.r. & $\mathrm{u}$ \\
\hline $\begin{array}{l}\text { Glaucous Gull } \\
\text { Larus hyperboreus }\end{array}$ & 1 June-15 Aug. & 1 May-31 Aug. & n.r. & $\mathrm{u}$ \\
\hline $\begin{array}{l}\text { Great Black-backed Gull } \\
\text { Larus marinus }\end{array}$ & 1 June-15 Aug. & 1 May-1 Aug. & n.r. & $\mathrm{u}$ \\
\hline $\begin{array}{l}\text { Black-legged Kittiwake } \\
\text { Rissa tridactyla }\end{array}$ & 1 June-15 Aug. & 1 Mar.-31 Aug. & 58,095 & 6 \\
\hline $\begin{array}{l}\text { Ivory Gull } \\
\text { Pagophila eburnea }\end{array}$ & Fully protected & Fully protected & - & - \\
\hline $\begin{array}{l}\text { Common Guillemot } \\
\text { Uria aalge }\end{array}$ & 15 Mar.-15 Oct. & 1 Mar.-14 Oct. & n.r. & u. \\
\hline $\begin{array}{l}\text { Brünnich's Guillemot } \\
\text { Uria lomvia }\end{array}$ & 15 Mar.-15 Oct. & 1 Mar.-14 Oct. & 254,728 & 72 \\
\hline $\begin{array}{l}\text { Razorbill } \\
\text { Alca torda }\end{array}$ & Fully protected & Fully protected & - & - \\
\hline $\begin{array}{l}\text { Black Guillemot } \\
\text { Cepphus grylle }\end{array}$ & 1 June-15 Aug. & 1 Mar.-31 Aug. & 35,058 & 32 \\
\hline $\begin{array}{l}\text { Little Auk } \\
\text { Alle alle }\end{array}$ & 1 June-15 Aug. & 1 May-31 Aug. & 64,494 & 2 \\
\hline $\begin{array}{l}\text { Atlantic Puffin } \\
\text { Fratercula arctica }\end{array}$ & Fully protected & Fully protected & - & - \\
\hline
\end{tabular}

N.r., not reported by the bag-record system; u., unknown.

in and off the mouth of the fjord Afersiorfik (Figures 3 and 4). Fast-ice usually forms in the fjords during the winter: to the south only in the interior parts, further north often throughout the fjords, but particular fjords may remain 


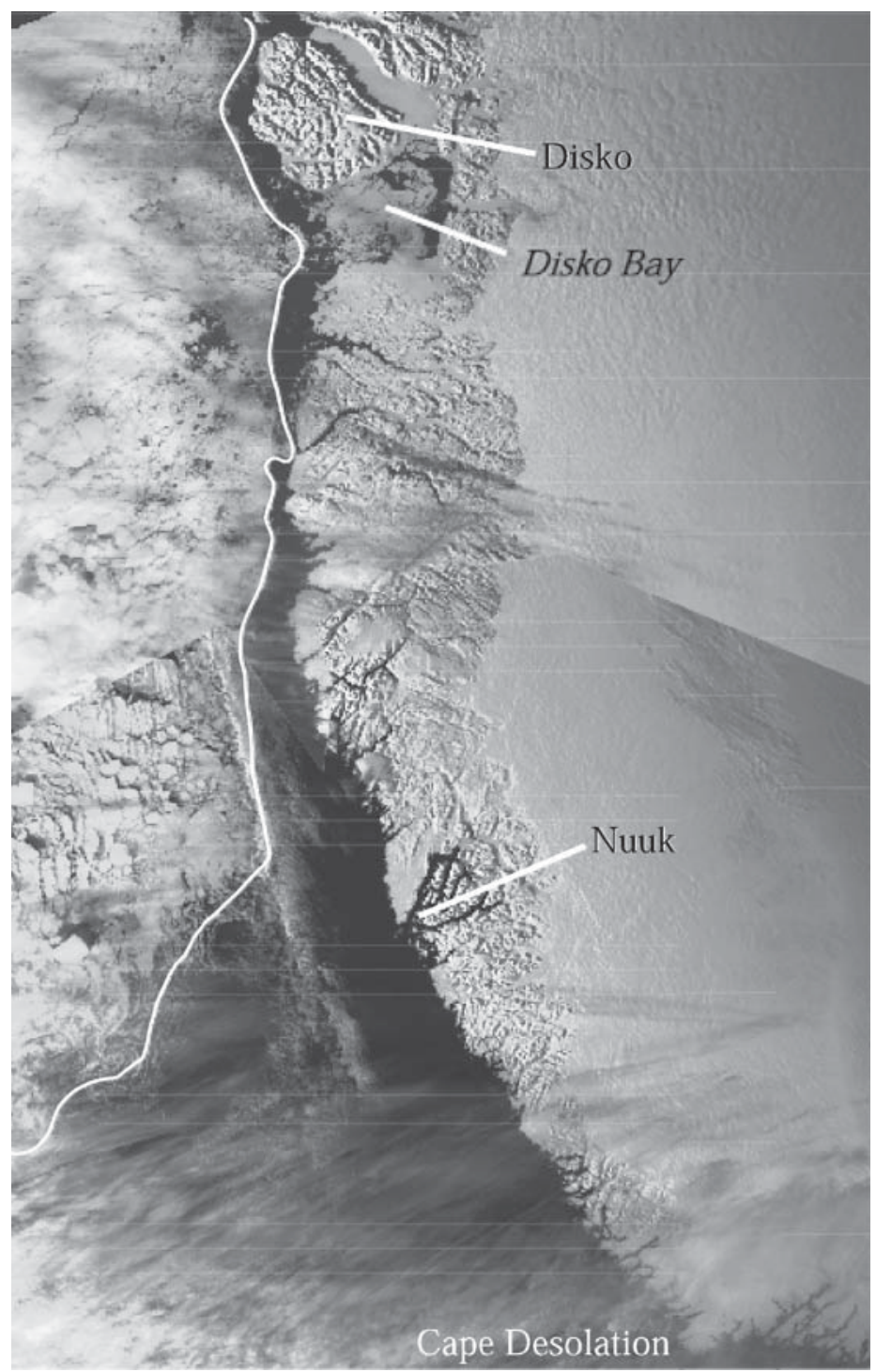

Figure 3. AA-AVHRR satellite image (Ch. 1) from 24 March 1998. Mosaic of two images. The white line indicates the approximate edge of the drift-ice in Davis Strait. Extensive open water is present along the coast north of Nuuk, even beyond Disko Island and in Disko Bay.

ice-free. In the northern part of the region, fast-ice also forms in the archipelagos and as a rim along the coasts, particularly during cold spells (Mosbech et al. 2000).

In the northern part of Southwest Greenland (Figure 1) the continental shelf (to the $200 \mathrm{~m}$ isobath) is about $150 \mathrm{~km}$ wide. This shelf gradually narrows towards the south and is about $50 \mathrm{~km}$ wide at $62^{\circ} \mathrm{N}$. Locally there are shallow areas with water depths of less than $50 \mathrm{~m}$. Trenches (> $200 \mathrm{~m}$ deep) more or less 


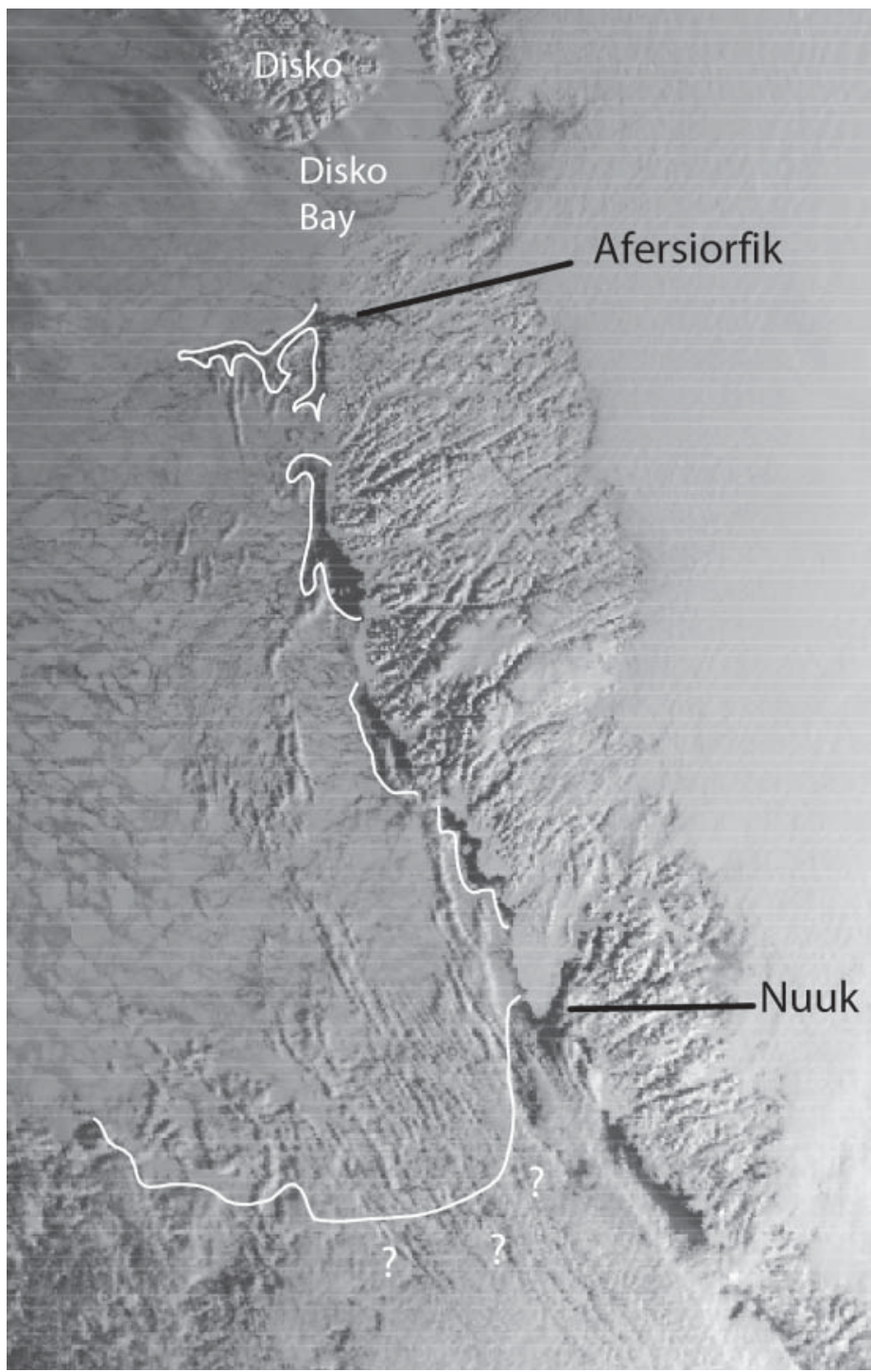

Figure 4. AA-AVHRR satellite image (Ch. 1) from 1o March 1997. The white line indicates the approximate edge of the drift-ice in Davis Strait. This image was taken during a very cold spell, when the ice covered most of the sea north of Nuuk. Only rather small openwater areas are apparent close to the shore. In the southern part, clouds obscure the ice distribution.

perpendicular to the coast traverse the shelf, dividing it into several separate banks.

During the summer, the gross primary production of the shelf waters has been measured to be as high as $900 \mathrm{mg} \mathrm{C} \mathrm{m}^{-2}$ day $^{-1}$, and annual production has been estimated at $160 \mathrm{~g} \mathrm{C} \mathrm{m}^{-2}$ year $^{-1}$ (Smidt 1979). This is high compared even with temperate seas, and is caused by upwelling events and the mixture of different 
water masses. Higher-trophic-level organisms such as seabirds and marine mammals feed on the abundant planktonic crustaceans and schooling fishes, e.g. Capelin Mallotus villosus and Sandeel Ammodytes spp. (Kapel 1979, 1995, Falk and Durinck 1993, Mosbech et al. 1998, Pedersen and Smidt 2000). Until about 1970 the area supported one of the largest offshore Atlantic Cod Gadus morhua fisheries in the world, peaking at almost 500,000 tons in 1962. However, the cod stock declined and almost disappeared about 1980, probably as a result of changes in oceanographic conditions (Horsted 2000, Petersen et al. 2001) in combination with the high fishing pressure. Dramatic changes have also occurred among other groundfish stocks of the offshore banks (Rätz 1999).

The higher trophic levels are represented by seabirds and marine mammals. Among the latter, Harp Seals Phoca groenlandica and baleen whales predominate in the summer (Kapel 1996, Mosbech et al. 1998). Many of these move out of the region for the winter and are replaced by Walruses Odobenus rosmarus, Bearded Seals Erignathus barbatus, Greenland Whales Balaena mysticetus, White Whales Delphinapterus leucas and Narwhals Monodon monoceros, all of which occur mainly in the drift-ice of the northern part of the region (Heide-Jørgensen et al. 1993, 2003, Born et al. 1994, Heide-Jørgensen 1994, Reeves and Heide-Jørgensen 1996, Boertmann et al. 1998, Heide-Jørgensen and Acquarone 2002).

\section{The seabirds wintering off Southwest Greenland}

\section{Northern Fulmar Fulmarus glacialis}

The highest number of fulmars reported from an entire survey was 5,847 in 1981 . This is low compared with this species' occurrence in the summer. Many fewer were recorded during the other surveys. Fulmars generally occur very patchily and seem to avoid areas with heavy ice-cover (exceeding 5/10). The few winter recoveries of ringed birds give no clue to the origin of the fulmars that winter in Southwest Greenland (Table 3), but most likely they are from Baffin Bay breeding populations. Numbers of fulmars present in the region in the winter are unknown, but probably highly variable according to ice and hydrographic conditions.

\section{Great Cormorant Phalacrocorax carbo}

Great Cormorants were recorded scattered along the coast throughout the region, with a total of 556 observed on the transects in 1999. Winter-time recoveries (Table 3) have been distributed throughout Southwest Greenland, and in midwinter (December-February) most birds were recovered from central Southwest Greenland (Maniitsoq and Nuuk). The Greenland population is probably discrete (Boertmann and Mosbech 1997).

The total number of Great Cormorants wintering in Southwest Greenland was roughly estimated at 15,000 birds based on a breeding estimate of 2,000-3,000 pairs in 1995 (Boertmann and Mosbech 1997). The population in Greenland has, however, increased and expanded its breeding range since then (Boertmann and Mosbech 1997, pers. obs.) and the winter population may be considerably larger now. 


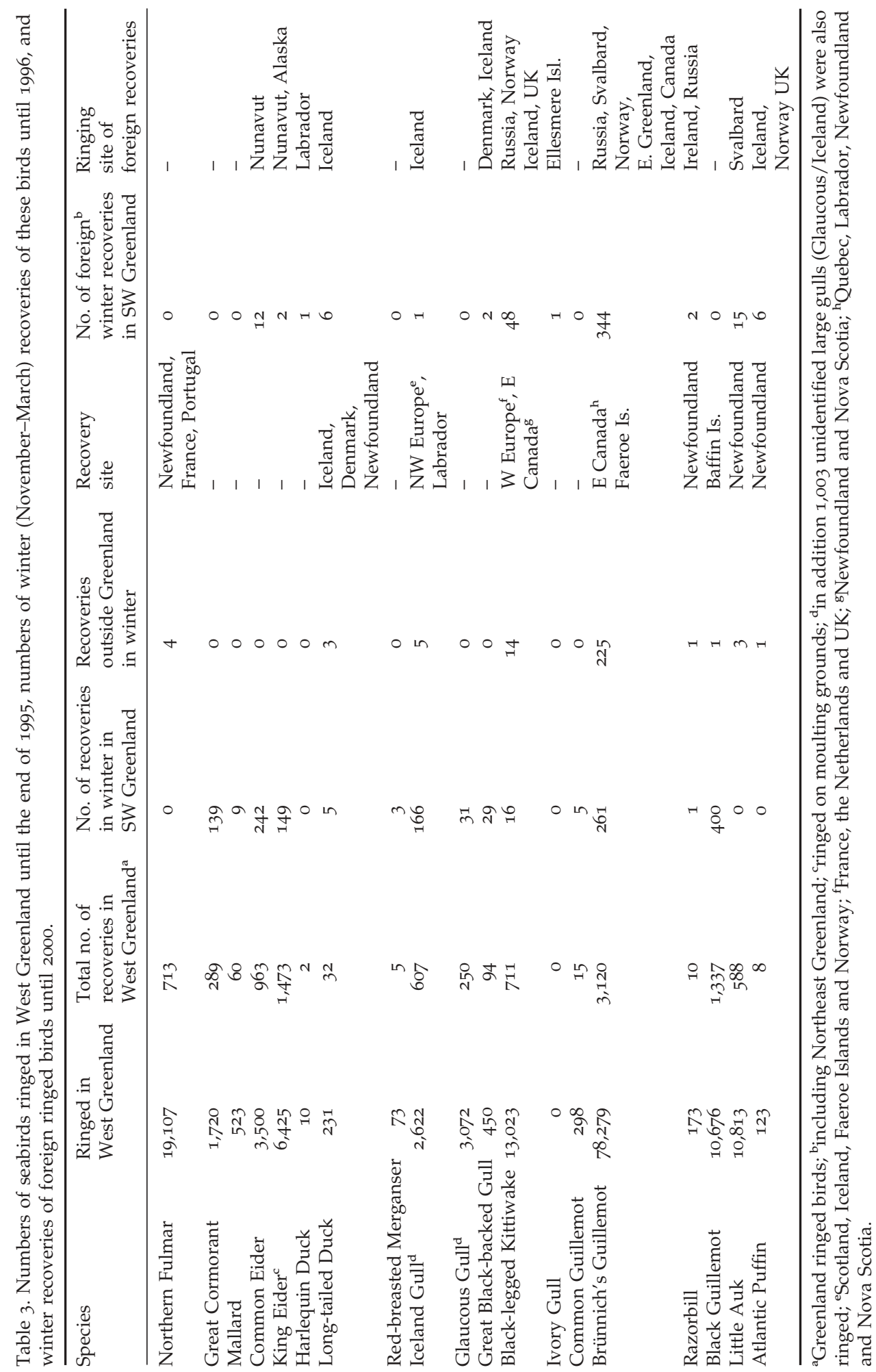


Mallard

Mallards were only observed in March 1999, when a total of 252 birds were counted in nearshore areas. Greenland Mallard is regarded as an endemic subspecies (conboschas), deviating from other subspecies mainly by its significantly larger body size (Brehm 1831). The few ring recoveries (Table 3) indicate that Greenland Mallards undertake only local movements. Many succumb in harsh winters when coastal feeding grounds are covered by ice (Salomonsen 1950), and the population size is therefore highly variable between years.

\section{Common Eider Somateria mollissima}

Common Eider was observed during all the surveys and it was one of the most numerous species in nearshore waters. Based on the March 1999 survey, the winter population was estimated at a little less than 500,000 birds, with large concentrations in Julianehåb Bay, in the Nuuk region and in the mouth of Afersiorfik (Merkel et al. 2002).

The entire breeding population of Common Eiders in western Greenland is estimated at roughly 12,000-15,000 pairs, with the majority breeding in Qaanaaq (Christensen and Falk 2001, Merkel 2002). These low numbers cannot account for the large winter population in Southwest Greenland. It was recently confirmed by ring recoveries and satellite telemetry (G. Gilchrist and A. Mosbech unpubl. data) that Common Eiders from Canadian breeding areas contribute in high proportions. The recoveries of Common Eiders ringed in Greenland (Table 3) indicate that birds from Northwest Greenland and Qaanaaq winter mainly in the northern part of Southwest Greenland from Maniitsoq to as far north as the ice allows. The sedentary breeding population in Southwest Greenland is very small, and the high numbers wintering here may be explained by birds with a Canadian breeding origin (Merkel et al. 2002, Merkel 2002). It is not known whether Common Eiders from Southeast Greenland move to Southwest Greenland for the winter. The size of the Southeast Greenland population is unknown, but recent observations (D. Boertmann unpubl. data) indicate that significant numbers may breed there. The rare occurrence in Southwest Greenland of the subspecies v-nigrum from arctic Canada and Alaska is another indication that Common Eiders from North America are present (Boertmann 1994).

King and Common Eiders are (along with Brünnich's Guillemots) the most important birds to Greenland hunters. Earlier estimates of bagged eiders (both species, combined) were about 144,00o birds annually (Salomonsen 1967, Kapel and Petersen 1982). The newly introduced bag-record reports indicate an average of 73,000 eiders shot annually from 1994 to 1999 (Namminersornerullutik Oqartussat 2000, 2002). Of these, 53\% were taken in Southwest Greenland in the winter and a further $20 \%$ in April and May.

In conclusion, about half a million Common Eiders winter in Southwest Greenland, representing breeding populations from Southwest Greenland, Northwest Greenland, Qaanaaq, Northeast Canada and perhaps Southeast Greenland. 


\section{King Eider}

King Eiders were found mainly in shallow parts of the offshore banks, inside the $50 \mathrm{~m}$ isobath (Mosbech and Johnson 1999). They also occurred with Common Eiders in the extensive archipelagos along the coast, and to a minor extent in the fjords. Huge concentrations were recorded on Store Hellefiskebanke where 261,000 birds were estimated in the winters 1991 and 1993 (Mosbech and Johnson 1999). In winter, the sea there is covered with drift-ice, and the King Eiders are found in small leads and cracks. For example, a single lead contained at least 20,000 birds in March 1993. Significant concentrations have also been recorded on similar bank habitats on Lille Hellefiskebanke, but not as regularly as on Store Hellefiskebanke. Further south, about 10,000 King Eiders were observed on Fyllas Banke during the ship survey in February/March 1989 (Durinck and Falk 1996).

King Eiders begin to arrive at moulting grounds in Northwest Greenland in July: males first, later followed by females and juvenile birds (Salomonsen 1968, Frimer 1993, 1994, Mosbech and Boertmann 1999). Ring recoveries in the spring and summer $(n=25)$ show that these birds are from Canadian Arctic breeding areas, west to about McClure Strait and McClintock Channel. Birds from areas further west may occur as well, because two birds ringed as chicks on Bathurst Island, Canada, and in Prudhoe Bay, Alaska, were subsequently recovered in Southwest Greenland. From late October, King Eiders arrive at the winter grounds on Store Hellefiskebanke (Mosbech et al. 2001). Winter ring-recoveries are distributed throughout Southwest Greenland except the extreme south (Table 3).

The number of moulting birds in Northwest Greenland has recently been estimated at 30,000-40,000 birds in late August, when numbers peak at moulting sites at Disko Island (Mosbech and Boertmann 1999). Additional birds may, however, moult in Northwest Greenland as the moulting period extends from late July well into October (Frimer 1994). The size of the winter population as an overall estimate covering the banks in 1981-1982 reached 270,000 birds (Mosbech and Johnson 1999). Merkel et al. (2002) estimated 153,000 King Eiders in the coastal zone (excluding the main habitats on the offshore banks) in 1999. These estimates are difficult to combine as birds may have been distributed differently in the two survey periods. However, it can be concluded that very high numbers of King Eiders winter in Southwest Greenland waters, roughly estimated at a minimum of 300,000 birds. They comprise breeding populations from Arctic Canada at least as far west as $110^{\circ} \mathrm{W}$, and probably also from North Greenland, where the number of breeding birds is, however, comparatively low (Boertmann 1994).

During 1993-1999, between 4,000 and 5,500 King Eiders were reported to the bag-record annually. These figures are obviously too low, because the hunters do not always discriminate between the two eider species and up to $50 \%$ of the eiders offered for sale at the markets in Nuuk in Southwest Greenland during the peak period for eider hunting are King Eiders (Frich 1997b).

\section{Harlequin Duck}

Harlequin Ducks were only observed in March 1999, during the coastal survey, when four flocks were located totalling 45 birds (Merkel et al. 2002). However, 
the winter surveys were not designed to detect these small and elusive ducks (see Boertmann and Mosbech 2002), and the survey results may not accurately reflect the actual abundance of this species. Other evidence indicates that substantial numbers of Harlequin Ducks winter along exposed coasts from Maniitsoq and southwards, with the majority between Nuuk and Cape Desolation (Boertmann 2004). Male Harlequin Ducks from the eastern Canadian population have recently been tracked by satellite telemetry to moulting and wintering grounds along Southwest Greenland coasts and a single ringed Canadian bird was recovered near Nuuk in August 1999 (Brodeur et al. 2002). An estimated 5,000-10,000 males moult in July in Southwest Greenland (Boertmann and Mosbech 2002). If all males stay in Greenland accompanied by females and juveniles, the winter population is substantially higher.

\section{Long-tailed Duck Clangula hyemalis}

Long-tailed Ducks were observed by the surveys covering the coastal areas in 1989, 1998 and 1999. In March 1999 Long-tailed Ducks were most frequent southwards from Nuuk, and a total estimate in the coastal zone was 94,00o birds (Merkel et al. 2002). Concentrations were located in the Nuuk area, in accordance with observations during the February/March 1989 survey (Durinck and Falk 1996).

Judging from ring recoveries (Table 3), some local Greenland birds winter in Southwest Greenland, especially south of Maniitsoq. Other Greenland birds seem to winter abroad, as there are a few recoveries from Europe and North America (Table 3). However, the ring recoveries also show that at least some Long-tailed Ducks breeding in Iceland (2,000-3,000 pairs; Petersen 2000) winter in Southwest Greenland, particularly in the southernmost parts. Long-tailed Ducks from Canada probably also occur in Southwest Greenland. The evidence is indirect, as a chick ringed in Greenland was recovered in Northwest Canada. This bird probably abmigrated with a Canadian female to its breeding grounds close to the Mackenzie River delta (Salomonsen 1967).

\section{Red-breasted Merganser Mergus serrator}

Red-breasted Mergansers were observed only during the March 1999 survey and in low numbers $(n=79)$. They were strictly confined to the coastal zone, and the majority were found south of Nuuk (Merkel et al. 2002). This is in agreement with previous knowledge (Salomonsen 1967). The few winter recoveries in Southwest Greenland indicate that birds from Northwest Greenland move southwards to the open waters of Southwest Greenland and that the Southwest Greenland birds are resident (Table 3). The morphology of birds from the West Greenland breeding population differs slightly from that of other populations (Salomonsen 1949), indicating discreteness. The Southwest Greenland winter population is small. Concentrations of up to 1,000 birds have been found at a few sites in Southwest Greenland during the summer moulting period (Boertmann and Mosbech 2001a) and in the autumn (F. Merkel unpubl. data), but winter congregations have not been documented. 


\section{Iceland Gull Larus glaucoides and Glaucous Gull L. hyperboreus}

These gulls were observed frequently during all the surveys. However, only the ship survey in 1989 discriminated between the species, and numbers were not quantified during the 1991 to 1999 aerial surveys. The general picture is that these gulls avoid heavy ice-cover and occur very patchily, occasionally in large local concentrations, e.g. where trawlers operate and in fishing ports and harbours. There were about 2,500 Glaucous Gulls and 7,000 Iceland Gulls in a $6,000 \mathrm{~km}^{2}$ area with moderate ice-cover off Nuuk in February/March 1989 (Durinck and Falk 1996).

Ring recoveries (Table 3) show that the Iceland Gulls from Greenland winter mainly in the Southwest Greenland area. However, a few Canadian birds also occur there, as the Baffin Island subspecies kumlieni (Kumlien's Gull) is reported regularly (Boertmann 1994, 2001, Boertmann and Mosbech 1999). Glaucous Gulls from Greenland winter mainly in Southwest Greenland (Table 3). Six Svalbard birds were recovered from West Greenland in summer and autumn as far north as Upernavik, indicating that some may stay in the winter. It seems likely that Canadian Glaucous Gulls also contribute to the winter population, as do Kumlien's Gulls and Brünnich's Guillemots from the western side of Baffin Bay, but no ring recoveries are available to support this supposition.

The breeding populations of Iceland Gulls and Glaucous Gulls in West Greenland can be roughly estimated at 20,000-100,000 pairs each (Boertmann et al. 1996), indicating that perhaps more than 300,000 of each species stay in Southwest Greenland during the winter.

\section{Great Black-backed Gull Larus marinus}

This gull was observed during all surveys. It was widespread but usually occurred in much lower numbers than the other two Larus species. The distribution of Great Black-backed Gulls seems to be less affected by heavy ice-cover than the other two species (Mosbech and Johnson 1999), and Durinck and Falk (1996) even found that they avoided open water. Large concentrations are occasionally observed. For example, about 9,500 were estimated to be present in a 6,000 $\mathrm{km}^{2}$ area with moderate ice-cover off Nuuk in February/March 1989 (Durinck and Falk 1996).

The winter population in Southwest Greenland consists of local birds. A few ring recoveries show that birds from Iceland and Northwest Europe do occur, but probably only as stragglers (Table 3). The breeding population is roughly estimated at 3,000-5,000 pairs (Boertmann et al. 1996), indicating a winter population of perhaps 25,000 individuals.

\section{Black-legged Kittiwake Rissa tridactyla}

The highest number of kittiwakes observed during a survey was 32 in March 1999, excluding a large assemblage at a breeding site inside a fjord. The bag record and ring recoveries indicate that, compared with eiders and Brünnich's Guillemots, kittiwakes occur only in small numbers in Southwest Greenland in the winter (Tables 2 and 3). Kittiwakes tend to avoid ice-cover greater than 5/10, 
and their occurrence resembles that of fulmars (Mosbech and Johnson 1999, Merkel et al. 2002).

Both Greenland and foreign birds occur in Southwest Greenland in the winter (Table 3).

\section{Ivory Gull Pagophila eburnea}

This high arctic gull was reported only from the survey in March $1982(n=14$, in Greenland waters), a year with heavy ice-cover. Elsewhere in Southwest Greenland it is known as an irregular or rare winter visitor to harbours and fishing ports (Salomonsen 1967, Boertmann 1994). In May 1979 considerable numbers were recorded in the drift-ice west of Disko Island (Kampp and Kristensen 1980). The main winter quarters for Ivory Gulls are apparently along the drift-ice edge in southern Davis Strait and the Labrador Sea, which is outside the Greenland area (Hjort 1976, Renaud and McLaren 1982, Orr and Parsons 1982, Haney and MacDonald 1995).

\section{Brünnich's Guillemot Uria lomvia}

This alcid is generally assumed to be the most numerous seabird in Southwest Greenland waters in the winter. Indeed, it was one of the most numerous species observed during the surveys. However, it is rather inconspicuous from an aircraft and therefore was probably not recorded efficiently during the aerial surveys.

Brünnich's Guillemots begin to occur on the banks in October, and as the winter progresses they move closer to the coast and inside the fjords (Mosbech et al. 1998). Movement towards the breeding grounds is initiated in March (Falk and Kampp 2001). In 1989, about 170,000 were estimated to be present in a $6,000 \mathrm{~km}^{2}$ area west of Nuuk (Durinck and Falk 1996). Most were seen in areas with moderate ice-cover, although about 30\% were recorded in small openings in heavy drift-ice. The surveys reported by Mosbech and Johnson (1999) showed that they tended to avoid dense pack-ice and were variably abundant in all other ice conditions, probably governed by prey distribution. Merkel et al. (2002) estimated about 125,000 individuals in the coastal zone of Southwest Greenland in March 1999. However, they are abundant further offshore, so this estimate is probably negatively biased. Several ship surveys in September and October through the 1990s resulted in a crude autumn estimate of more than 650,000 Brünnich's Guillemots present in the surveyed area, which covered only a part of their total autumn range (Boertmann and Mosbech 2001b).

Brünnich's Guillemot is the most popular game bird in West Greenland. In the winter of 1988-1989 Falk and Durinck (1992) estimated the number of bagged birds in West Greenland at $283,000-386,000$, of which about $82 \%$ were taken in Southwest Greenland. Since then, the bag-record system has been introduced and the total number of reported Brünnich's Guillemots has ranged between 188 ,000 and 255,000 , of which $72 \%$ were from Southwest Greenland in the winter, and a further 3.3\% in April and May (Namminersornerullutik Oqartussat 2000). A preliminary assessment of the bag record in 1993 indicated that the reported catch was lower than the actual catch in some areas (Frich 1997a). 
More than 600 ringed Brünnich's Guillemots have been recovered in winter in Southwest Greenland, of which 43\% originated from colonies in West Greenland (Table 3). Generally, West Greenland and probably also Qaanaaq birds winter partly in Southwest Greenland north as far as the ice allows and partly off eastern Canada from Newfoundland south to Nova Scotia (Kampp 1988). Large numbers of birds from Canada and the Northeast Atlantic also winter in Southwest Greenland. More than half of the winter recoveries from Southwest Greenland are birds ringed in those areas (Table 3). Canadian birds from colonies in north-western Baffin Bay have been recovered mainly from the waters north of Nuuk. Guillemots from Svalbard and small numbers from East Greenland, Iceland, Bjørnøya, mainland Norway and Russia have been recovered from the region between Nanortalik and Maniitsoq (Kampp 1988, Falk and Kampp 2001).

The total number of Brünnich's Guillemots wintering in Southwest Greenland is unknown, but may reach some millions, judging from the large harvest.

\section{Black Guillemot Cepphus grylle}

Black Guillemots were observed to be widespread, but in much smaller numbers than eiders and Brünnich's Guillemot, during all the surveys. For example, only 865 birds were recorded in March 1999 (Merkel et al. 2002). Mosbech and Johnson (1999) reported Black Guillemots to be widely dispersed in dense packice throughout Davis Strait, in accordance with previous observations in Baffin Bay (Renaud and Bradstreet 1980). Durinck and Falk (1996) also found most Black Guillemots in heavy ice-cover, and estimated about 25,000 birds in a $6,000 \mathrm{~km}^{2}$ area with moderate ice-cover off Nuuk. Merkel et al. (2002) estimated 12,000 Black Guillemots in the coastal zone along Southwest Greenland in March 1999, a zone that covers only a small fraction of the winter range.

Black Guillemots are shot in smaller numbers than eiders and Brünnich's Guillemots (Table 2). This reflects both their more dispersed distribution and the fact that many hunters consider them as secondary quarry due to their relatively small size.

Many ring recoveries confirm that West Greenland Black Guillemots winter in Southwest Greenland (Table 3). Birds from Upernavik and Uummannaq, mainly belonging to the subspecies mandtii, winter in the northern part of the Southwest Greenland region south to about Nuuk, although a few have been recovered south as far as Qaqortoq. Southwest Greenland breeders (subspecies arcticus) are mostly sedentary, wintering close to their breeding sites. Two late autumn recoveries indicate that a few Black Guillemots from Iceland contribute to the winter population. It also seems likely that birds from the Canadian side of Baffin Bay are present in Southwest Greenland waters during the winter.

\section{Little Auk Alle alle}

Little Auks were only observed during the ship survey in February/March 1989. The species is too small to be surveyed effectively from the air, so it is usually omitted from the results of aerial surveys (Mosbech and Johnson 1999, Merkel et al. 2002). In 1989, Little Auks were found in low densities (1.2 birds $/ \mathrm{km}^{2}$ ) in a $6,000 \mathrm{~km}^{2}$ area with moderate ice-cover off Nuuk (Durinck and Falk 1996). Very 
few were observed further south. The literature (Salomonsen 1967) indicates that Little Auks are common in the winter in Southwest Greenland, with the highest numbers in the southern part.

Hunters in Southwest Greenland consider the Little Auk a secondary quarry compared with the larger species such as guillemots and eiders, and the reported bag-records (in Southwest Greenland) do not reflect the numbers present in the area (Table 2).

None of the 10,000 Little Auks ringed in North Greenland (Qaanaaq) have been recovered there, and ring recoveries indicate that most of the Little Auks present in Southwest Greenland during the winter are from Svalbard (Table 3). Substantial numbers begin to arrive in the northern part of Southwest Greenland in early September (Christensen and Lear 1977), and it is unlikely that they would be from any breeding area other than North Greenland. Three recoveries show that at least some of the North Greenland Little Auks reach waters off Newfoundland for the winter. It therefore seems likely that Little Auks from North Greenland, Svalbard and perhaps also East Greenland stay at least temporarily somewhere in Southwest Greenland during the winter. Their numbers are unknown. Recent estimates of the breeding population in North Greenland have ranged from 20 million to 36 million pairs (Boertmann and Mosbech 1998, Egevang et al. 2003). As these birds migrate to or through Davis Strait, the numbers wintering in Southwest Greenland could be substantial.

\section{Other species occurring in Southwest Greenland waters during winter}

Common Guillemot Uria aalge, Razorbill Alca torda and Atlantic Puffin Fratercula arctica were not observed during the surveys. However, other evidence and ring recoveries (Table 3 ) indicate that these species winter in small numbers in Southwest Greenland. For example, of 6,278 guillemots shot in Southwest Greenland during the winter 1988-1989, seven (0.01\%) were Common Guillemots (Falk and Durinck 1992) and a few Razorbills have regularly been found among bagged Brünnich's Guillemots (Boertmann 1994). Two coastal bird species are also dependent upon the open waters off Southwest Greenland in the winter. Approximately 500 White-tailed Eagles Haliaeetus albicilla from the discrete local population and some thousands of Purple Sandpipers Calidris maritima winter there. Even land birds, such as Gyr Falcons Falco rusticolus, Snowy Owls Nyctea scandiaca and Ravens Corvus corax, remain and feed in the drift-ice far from land.

\section{Numbers and trends}

The total number of birds wintering in Southwest Greenland is roughly estimated at a minimum of 3.5 million (Table 4 ). This is of course a very crude estimate because for some species the figures are nothing more than educated guesswork. However, we believe that this is an underestimate, and that the actual numbers present are likely to be considerably higher. Little Auks are not included in the total estimate, as we have no idea of their abundance during the winter, but there could be several million of them.

During summer, the number of breeding colonial seabirds in Southwest Greenland is estimated at about 200,000 individuals (Boertmann et al. 1996). 
Table 4. Overview of the different flyway populations of seabirds wintering in Southwest Greenland, based on the surveys reported here, literature, own observations and number of breeding birds in western Greenland (Boertmann et al. 1996).

\begin{tabular}{|c|c|c|}
\hline Species & $\begin{array}{l}\text { Supposed } \\
\text { numbers } \\
\text { in winter }\end{array}$ & $\begin{array}{l}\text { Flyway populations (and part wintering } \\
\text { in SW Greenland) }\end{array}$ \\
\hline Northern Fulmar & $<100,000$ & Probably Baffin Bay area (i) \\
\hline Great Cormorant & $15,000^{\mathrm{b}}$ & W Greenland (100\%) \\
\hline Mallard & $<50, \mathrm{OOO}^{\mathrm{c}}$ & W and SE Greenland $(\geq 95 \%)$ \\
\hline Common Eider & $\geq 500,000^{\mathrm{a}}$ & $\mathrm{N}$ and $\mathrm{W}$ Greenland $(100 \%)$, NE Canada $(80 \%)$ \\
\hline King Eider & $\geq 300,000^{\mathrm{a}}$ & NE Canada (100\%?), N Greenland (x) \\
\hline Harlequin Duck & $>10,000^{b}$ & W Greenland (100\%), E Canada $\left(\geq_{50} \% ?\right)$ \\
\hline Long-tailed Duck & $\geq 100,000^{\mathrm{a}}$ & Greenland (x), Iceland (x), Canada? \\
\hline Red-breasted Merganser & $<20, \mathrm{OOO}^{\mathrm{c}}$ & W Greenland (100\%) \\
\hline Iceland Gull & $\geq 300,000^{3}$ & Greenland ( $\geq 90 \%)$, NE Canada (i) \\
\hline Glaucous Gull & $\geq 00,000^{3}$ & Greenland ( $\geq 75 \%$ ?), Svalbard (i), NE Canada? \\
\hline Great Black-backed Gull & $25,000^{c}$ & W Greenland (100\%), NW Europe (i) \\
\hline Black-legged Kittiwake & few $^{c}$ & North Atlantic (i) \\
\hline Ivory Gull & few $^{\mathrm{c}}$ & NE Greenland (i), NE Canada?, Svalbard? \\
\hline Common Guillemot & few $^{\mathrm{c}}$ & W Greenland (x), E Canada? \\
\hline Brünnich's Guillemot & $>1,500,000^{b}$ & $\begin{array}{l}\text { W, N Greenland (50\%?), Svalbard ( } 75 \% \text { ?), } \\
\text { NE Canada (50\%?), Iceland (x), Russia (x) }\end{array}$ \\
\hline Razorbill & few $^{\mathrm{c}}$ & Greenland (x), Russia (i), NW Europe (i) \\
\hline Black Guillemot & $\geq 250, \mathrm{OOO}^{\mathrm{c}}$ & W, N Greenland ( $\geq 75 \%$ ?), Iceland (i), Canada? \\
\hline Little Auk & unknown & Svalbard (x), N Greenland? \\
\hline Atlantic Puffin & few $^{\mathrm{c}}$ & Greenland (x), Iceland (x), NW Europe (i) \\
\hline Total & $\geq 3,476,000$ & \\
\hline
\end{tabular}

(i), insignificant part; (x), unknown part; (\%?), part guessed.

${ }^{\mathrm{a}}$ Reasonable estimate; ${ }^{\mathrm{b}}$ crude estimate, ${ }^{\mathrm{c}}$ educated guess.

These are mainly Black-legged Kittiwakes, gulls and some Brünnich's Guillemots. The numbers of non-colonial species are unknown, but are probably much lower. Additionally, a large contingent of non-breeding seabirds stays in Southwest Greenland waters during the summer. It consists mainly of immature birds from North Atlantic breeding populations of Black-legged Kittiwakes, Northern Fulmars and skuas Stercorarius spp. (Boertmann and Mosbech 2001b). Furthermore, Great Shearwaters Puffinus gravis from the South Atlantic are numerous in July-September (Salomonsen 1967, 1979a, Boertmann 1994, Huettmann and Diamond 2000). The numbers of these non-breeding birds are unknown, but may be in the order of 100,000 for the three most numerous species (Black-legged Kittiwake, Northern Fulmar and Great Shearwater).

It is remarkable that the numbers of seabirds utilizing the same region in summer are apparently so much lower than in winter and also that the feeding strategies of the various species differ between seasons. During the winter, diving birds predominate. They feed either on pelagic fishes and crustaceans (Brünnich's Guillemots, Little Auks) or on benthic fauna (the eiders). In the summer, surface-feeding species (Northern Fulmars, Great Shearwaters, Kittiwakes and gulls) predominate among both breeding and non-breeding birds while the number of diving birds is small. Perhaps prey in the water column is more concentrated and accessible in the winter than in the summer. 
The survey results give no indication of trends among the wintering birds in Southwest Greenland. However, anecdotal evidence indicates a serious decline in the eider population since the beginning of the 190os (e.g. Oldenow 1933). Surveys in the breeding areas of populations that winter in Southwest Greenland have shown declines: Brünnich's Guillemots in Greenland (Kampp et al. 1994) and Iceland (Petersen 2000), King Eiders in Canada (Gratto-Travor et al. 1998) and Common Eiders in Greenland (Boertmann et al. 1996, Merkel 2002). Also, the number of moulting King Eiders in West Greenland has decreased (Mosbech and Boertmann 1999). Only breeding, resident Great Black-backed Gulls and Great Cormorants have shown increasing trends in West Greenland recently (Boertmann 1994, Boertmann et al. 1996, unpublished information), so it is reasonable to infer that the wintering numbers of these species may also have increased.

\section{Winter hotspots}

It is possible to identify several winter hotspots for seabirds in the extensive region of Southwest Greenland (about $1,100 \mathrm{~km}$ in a straight line), and there may be several more. Most of the sites are located close to the coast and host species such as the Common Eider, King Eider and Long-tailed Duck that depend upon the predictable occurrence of benthic prey. Great Cormorants, Mallards and Red-breasted Mergansers may also occur in significant numbers. Such sites are mainly found at fjord mouths where tidal currents keep the waters free of ice even during very cold spells. In the mouth of Afersiorfik fjord (Figure 5, no. 1), about 30,000 Common Eiders and 200 Great Cormorants were observed in March 1999. Several settlements in this area provide a clear indication of the presence of adequate and predictable hunting resources (seabirds and seals) in the winter. In the mouth of Godthåb Fjord (Figure 5, no. 5), 57,000 Common Eiders and 13,000 Long-tailed Ducks were estimated in March 1999 (Merkel et al. 2002). The westernmost islands provide an important winter ground for Harlequin Ducks (Boertmann 2004), and Brünnich's Guillemots are often very abundant among the islands as well. Several small settlements were previously situated in this area, testifying to predictable hunting resources in the winter. In the southern part of the region, in Julianehåb Bay and adjacent fjords (Figure 5, nos. 6 and 7), about 95,000 Common Eiders were estimated in March 1999 (Merkel et al. 2002).

Offshore, King Eiders are the only seabirds presently known to occur in predictable areas. They are capable of diving to about $50 \mathrm{~m}$ depth (Bustness and Lønne 1997), and in the shallow parts of the banks the bottom fauna is available to them. The most important King Eider winter area is in the northern part of Store Hellefiskebanke (Fig. 5, no. 2). King Eiders have not been recorded regularly in other shallow bank habitats (Fig. 5, nos. 3 and 4). Perhaps these sites are utilized only when ice-cover forces them away from the northern part of Store Hellefiskebanke (Mosbech and Johnson 1999).

\section{International significance}

The international significance of the Southwest Greenland region is underlined by the breeding origins of the wintering seabirds. Birds ringed as far away as 


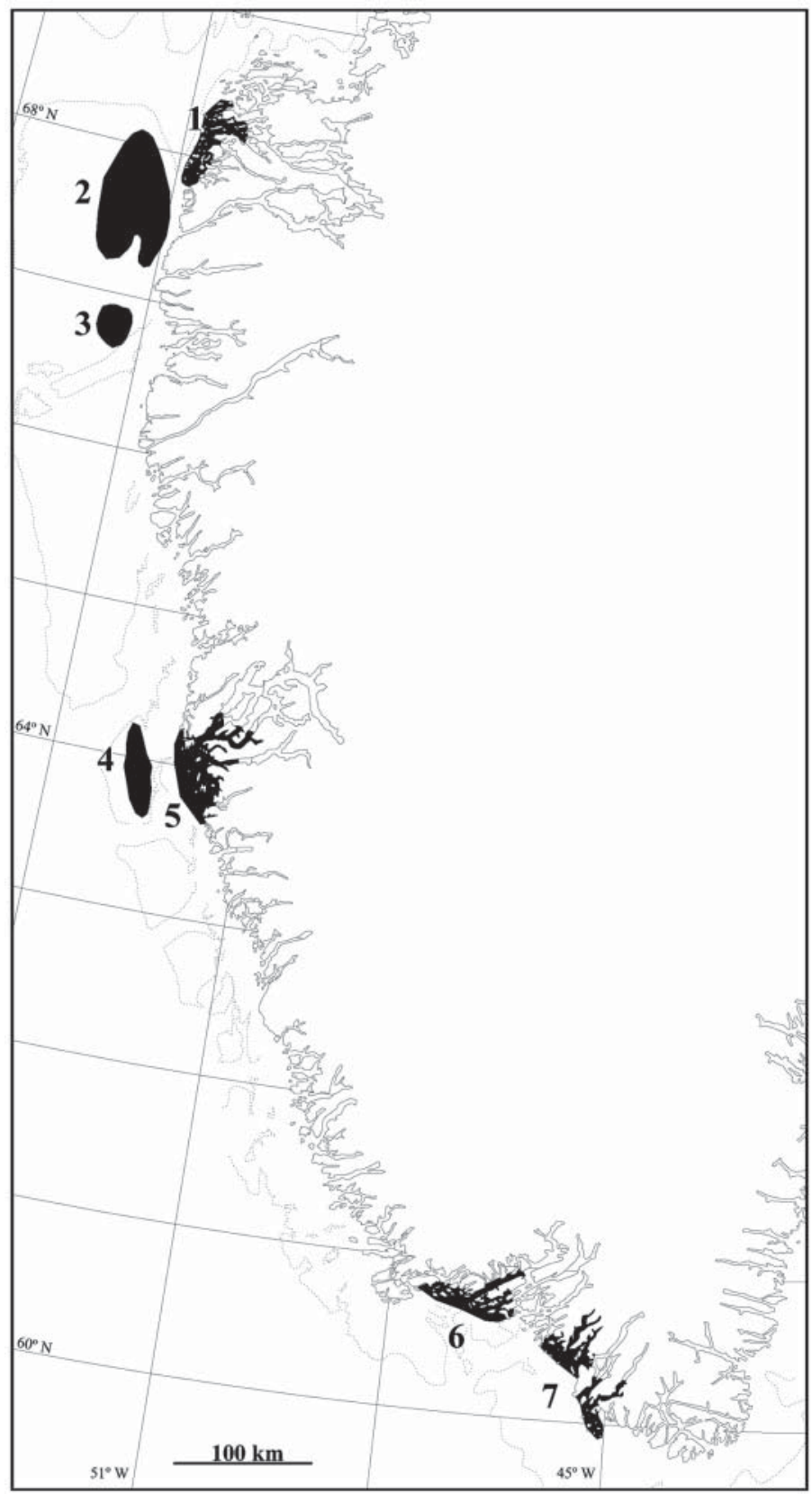

Figure 5. Currently known and predicted winter hotspots for seabirds in Southwest Greenland (most important birds mentioned in parentheses). 1, Mouth of Afersiorfik (Common Eider, Great Cormorant). 2, Shallow parts of northern Store Hellefiskebanke (King Eider). 3, Shallow parts of southern Store Hellefiskebanke (King Eider). 4, Fyllas Banke (King Eider). 5, mouth of Godthåb Fjord (Great Cormorant, Common Eider, Longtailed Duck, Harlequin Duck, Brünnich's Guillemot). 6, Northern part of Julianehåb Bay (Common Eider, Harlequin Duck, Brünnich's Guillemot). 7, Southern part of Julianehåb Bay (Common Eider). 
northern Alaska and Novaja Semlja in Russia have been recovered there. However, most of the wintering birds are from breeding populations in the Baffin Bay region and Svalbard. Internationally, Southwest Greenland is of particular importance to Brünnich's Guillemots that breed in Svalbard and arctic Canada and to Common and King Eiders from arctic Canada (see proportions of populations in Table 4). The region is also of utmost importance to many discrete Greenland populations, such as Great Cormorants, Mallards (endemic subspecies), Red-breasted Mergansers and White-tailed Eagles (considered an endemic subspecies by some authors, e.g. Salomonsen 1979).

To birds in the Baffin Bay region generally, Southwest Greenland provides the nearest predictable open-water area of considerable size and extent. Why many birds from Svalbard also winter there is more puzzling. Perhaps there is less competitive interaction with other diving birds in Southwest Greenland than there is in the much closer Norwegian and Icelandic waters, where large numbers of diving seabirds from local populations winter (see Nygård et al. 1988, Petersen 1998, Barrett et al. 2001).

\section{Threats}

Hunting seabirds and marine mammals is extremely important to Greenlanders, both as an occupation and as a leisure activity (Kapel and Petersen 1982, Pars et al. 2001). In Southwest Greenland most seabirds are harvested during the winter months, with Brünnich's Guillemot and eiders (Table 2) the primary targets. The importance of seabird hunting is underlined by the fact that only 38,000 people live in Southwest Greenland (Anon 2000), and their reported annual harvest reaches up to a quarter of a million seabirds. Moreover, preliminary studies have shown that the actual catch in some areas is even higher than reported (Frich 1997a, b). Declines in several breeding populations wintering in Southwest Greenland have been related to hunting in Southwest Greenland. For the Greenland breeding populations of Brünnich's Guillemots and Common Eiders, illegal hunting during the summer also plays a significant role, and the total harvests of these populations in Greenland are considered unsustainable (Kampp et al. 1994, Meltofte 2001, Merkel et al. 2002.).

Oil spills are a serious threat and a large spill in Southwest Greenland in winter could affect large numbers of seabirds (Mosbech et al. 1996, Mosbech 1997). Populations occurring in highly localized concentrations, such as King Eiders or Harlequin Ducks, are particularly vulnerable. Potential sources of oil spills in Southwest Greenland are transport vessels and offshore exploration sites. Some 200,000 tons of mainly fuel oil is transported annually through Southwest Greenland waters. Exploratory drilling took place in summer 2000 near Fyllas Banke (Christiansen et al. 2001) and more drilling is expected in the near future. Fortunately, the current oil spill threat to the wintering seabirds remains low, because transport and exploration take place only during the summer.

Present levels of incidental mortality of seabirds in fisheries in Southwest Greenland are unknown (Falk 1998). However, a rather intensive and increasing gillnet fishery for Lumpsucker Cyclopterus lumpus takes place in coastal waters, and preliminary studies indicate that many Common Eiders are caught by this 
fishery during the late winter and early spring (Merkel 2002). Previously, in the early 1970s, offshore and nearshore drift-net fisheries for Atlantic Salmon Salmo salar took huge numbers of Brünnich's Guillemots off Southwest Greenland, mainly in late autumn (Tull et al. 1972, Christensen and Lear 1977). This by-catch has declined to insignificant levels because the quota was reduced and the timing and location of the fishery were changed, eliminating much of the overlap with the occurrence of Brünnich's Guillemots (Falk and Durinck 1991).

Climate change scenarios for Greenland predict an increase in mean yearly temperature, most significantly in mid- and high latitudes of West Greenland, and the frequency of periods with extremely low temperatures is expected to decrease (Petersen et al. 2001). Such trends seem, at first sight, beneficial to most of the wintering seabirds (e.g. Common Eiders, King Eiders and Mallards), as reduced extent and duration of winter ice coverage should, for example, make more feeding habitat available. Species associated with drift-ice, e.g. Black Guillemots and Ivory Gulls, would, in contrast, encounter less favourable conditions. However, local studies of sea-ice extent in the Baffin Bay and Davis Strait regions showed a decrease in open-water areas in winter during recent decades (Stern and Heide-Jørgensen 2003, Heide-Jørgensen and Laidre unpubl. data). If this declining trend in open water continues, access to critical foraging areas may be reduced in winter and spring, causing concern for several of the bird populations wintering in Southwest Greenland (Heide-Jørgensen and Laidre unpubl. data). The issue of climate change should not be neglected in future management of seabird populations in Southwest Greenland.

\section{Conservation concerns}

The conservation of seabird populations in Southwest Greenland is supposed to be assured by hunting regulations, which were revised in January 2002 with the intention of achieving more sustainable harvest levels. Of greatest significance were the expansion of the closed season in spring, and the introduction of bag-limits for eiders and Brünnich's Guillemots taken by non-professional hunters. In particular, the Common Eider population may benefit from the reduced hunting in spring, as about $32 \%$ of the bagged birds were taken in March, April and May. However, due to immense pressure from the hunting organization, the Greenland government now (spring 2004) has reduced the closed season in spring by two weeks (Table 2).

Hunting is not spatially limited in Greenland, except for the immediate vicinity of cities and a few breeding bird sanctuaries (and only in summer). As the Greenland hunters travel in very fast dinghies, they can reach every site along the coast in a few hours (Nielsen 1998). Thus, there are no sites in coastal Southwest Greenland where seabirds can rest and feed during the winter without risk of being hunted or disturbed by hunting activities. Populations such as those of Common Eider and Long-tailed Duck that are confined to coastal habitats where the hunters operate are particularly vulnerable. King Eiders, in contrast, wintering far from the coast and in the drift-ice, are almost inaccessible to the hunters.

Recent experience from Denmark, where a network of shooting-free reserves has been established, shows that both local and migratory waterbird numbers and hunting in nearby areas benefit from areas where hunting is forbidden 
(Fox and Madsen 1997, Madsen 1998a, b, Madsen and Clausen 1998). We are confident that a similar network in Southwest Greenland coastal areas would also be beneficial, particularly to the Common Eider population, provided the stipulations of such hunting-free areas are observed.

\section{Acknowledgements}

Thanks go to two anonymous referees who improved the manuscript, and to Randall Reeves who improved the English.

\section{References}

Anon. (2000) Grønland 2000 Kalaallit Nunaat, Statistisk Årbog. Nuuk: Grønlands Statistik.

Barrett, R. T., Anker-Nilssen, T., Gabrielsen, G. W. and Chapdelaine, G. (2001) Food consumption by seabirds in Norwegian waters. ICES J. Mar. Sci. 59: 43-57.

Boertmann, D. (1994) An annotated checklist to the birds of Greenland. Meddelelser Grønland Biosci. 38: 1-63.

Boertmann, D. (2001) The Iceland Gull complex in Greenland. Br. Birds 94: 547-548.

Boertmann, D. (2004) Distribution and conservation of the Harlequin Duck, Histrionicus histrionicus, in Greenland. Can. Field-Nat. 117: 249-256.

Boertmann, D. and Mosbech, A. (1997) Breeding distribution and abundance of the great cormorant Phalacrocorax carbo carbo in Greenland. Polar Res. 16: 93-100.

Boertmann, D. and Mosbech, A. (1998) Distribution of little auk (Alle alle) breeding colonies in Thule District, northwest Greenland. Polar Biol. 19: 206-210.

Boertmann, D. and Mosbech, A. (1999) Bemærkelsesværdige fugleobservationer fra Vest- og Nordgrønland 1992-1998. Dansk Ornitol. Forenings Tidsskr. 93: 145-152.

Boertmann, D. and Mosbech, A. (2001a) Important summer concentrations of seaducks in West Greenland. An input to oil spill sensitivity mapping. National Environmental Research Institute, Denmark, Technical Report 345: 1-48 (http://www.dmu.dk/1_viden/ 2_Publikationer/3_fagrapporter/rapporter/fr345.pdf).

Boertmann, D. and Mosbech, A. (2001b) Offshore seabird distributions during summer and autumn at West Greenland. Ship based surveys 1977 and 1992-2000. National Environmental Research Institute, Technical Report 370. (http://www.dmu.dk/1_viden/ 2_Publikationer/3_fagrapporter/rapporter/fr370.pdf).

Boertmann, D. and Mosbech, A. (2002) Moulting Harlequin Ducks in Greenland. Waterbirds 25: 326-332.

Boertmann, D., Mosbech, A., Falk, K. and Kampp, K. (1996) Seabird colonies in western Greenland. National Environmental Research Institute, Technical Report 170.

Boertmann, D., Mosbech, A. and Johansen, P. (1998) A review of biological resources in West Greenland sensitive to oil spills during winter. National Environmental Research Institute, Technical Report 246.

Born, E. W. and Böcher, J. (2001) The ecology of Greenland. Nuuk: Ilinniusiorfik.

Born, E. W., Heide-Jørgensen, M. P. and Davis, R. A. (1994) The Atlantic walrus (Odebenus rosmarus rosmarus) in West Greenland. Meddelelser Grønland Biosci. 40: 1-33.

Brehm, C. L. (1831) Lehrbuch der Naturgeschichte aller Vögel Deutschlands. Ilmenau.

Brodeur, S., Savard, J.-P. L., Robert, M., Laporte, P., Lamonthe, P., Titman, R. D., Marchand, S., Gilliland, S. and Fitzgerald, G. (2002) Harlequin Duck Histrionicus histrionicus population structure in eastern Nearctic. J. Avian Biol. 33: 127-137.

Brown, R. G. B. and Nettleship, D. N. (1981) The biological significance of polynyas to arctic colonial seabirds. In I. Stirling and H. Cleator, eds. Polynyas in the Canadian arctic. Canadian Wildife Service, Occasional Papers 45. 
Bustnes, J. O. and Lønne, O. J. (1997) Habitat partitioning among sympatric wintering Common Eiders Somateriam mollissima and King Eiders Somateria spectabilis. Ibis 139: 549-554.

Christensen, K. D. and Falk, K. (2001) Status of the common eider breeding in the municipality of Avanersuaq (Thule), north-west Greenland. Polar Res. 20: 109-114.

Christensen, O. and Lear, W. H. (1977) Bycatches in salmon driftnets at West Greenland in 1972. Meddelelser om Grønland 205 (5).

Christiansen, F. G., Bojesen-Koefoed, J. A., Chalmers, J. A., Dalhoff, F., Mathiesen, A., Sønderholm, M., Dam, G., Gregersen, U., Marcussen, C., Nøhr-Hansen, H., Piasecki, S., Preuss, T., Pulvertaft, T. C. R., Rasmussen, J. A. and Sheldon, E. (2001) Petroleum geological activities in West Greenland in 2000. Review of Greenland activities 2000. Geol. Greenland Surv. Bull. 189: 24-33.

Durinck, J. and Falk, K. (1996) The distribution and abundance of seabirds off southwestern Greenland in autumn and winter 1988-1989. Polar Res. 15: 23-42.

Egevang, C., Boertmann, D., Mosbech, A. and Tamsdorf, M. P. (2003) Estimating colony area and population size of little auks Alle alle at Northumberland Island using aerial images. Polar Biol. 26: 8-13.

Falk, K. (1998) Review of seabird bycatch in Greenland. In V. Bakken and K. Falk, eds. Incidental take of seabirds in commercial fisheries in the Arctic countries. Circumpolar Seabird Working Group Technical Report 1.

Falk, K. and Durinck, J. (1991) The by-catch of Thick-billed Murres in salmon drift nets off West Greenland in 1998. In A. J. Gaston and R. D. Elliot, eds. Studies of high-latitude seabirds. 2. Conservation biology of Thick-billed Murres in the Northwest Atlantic. Canadian Wildlife Service, Occasional Papers 69.

Falk, K. and Durinck, J. (1992) Thick-billed murre hunting in West Greenland, 1988-89. Arctic 45: 167-178.

Falk, K. and Durinck, J. (1993) The winter diet of Thick-billed Murres, Uria lomvia, in western Greenland, 1988-89. Can. J. Zool. 71: 264-272.

Falk, K. and Kampp, K. (2001) Lomvien i Grønland: mulige effekter af forskellige bestandspåvirkende faktorer, og praktiske grænser for ressourceudnyttelse. Pinngortitaleriffik, Grønlands Naturinstitut, teknisk rapport 38.

Fox, A. D. and Madsen, J. (1997) Behavioural and distributional effects of hunting disturbance on waterbirds in Europe: implications for refuge design. J. Appl. Ecol. 34: $1-13$.

Frich, A. S. (1997a) Lomviefangst i Grønland 1993. Pinngortitaleriffik, Grønlands Naturinstitut, teknisk rapport 2.

Frich, A. S. (1997b) Ederfuglefangst i Grønland. Pinngortitaleriffik, Grønlands Naturinstitut, teknisk rapport 9.

Frimer, O. (1993) Occurrence and distribution of king eiders Somateria spectabilis and common eiders S. mollissima at Disko, West Greenland. Polar Res. 12: 111-116.

Frimer, O. (1994) Autumn arrival and moult in king eiders (Somateria spectabilis) at Disko, West Greenland. Arctic 47: 137-141.

Gratto-Travor, C. L., Johnston, V. H. and Pepper, S. (1998) Changes in shorebird and eider abundance in the Rasmussen Lowlands, NWT. Wilson Bull. 110: 316-325.

Grønlands Hjemmestyre (1989) Hjemmestyrets bekendtgørelse nr. 29 af 19. september 1989 om fredning af fugle i Grønland. Grønlands Hjemmestyre.

Grønlands Hjemmestyre (2004) Hjemmestyrets bekendtgørelse nr. 1 af 21. januar 2004 om beskyttelse af fugle i Grønland. Grønlands Hjemmestyre.

Haney, J. C. and MacDonald, S. D. (1995) Ivory Gull Pagophila eburnea. In A. Poole and F. Gill, eds. The birds of North America 175. The American Ornithologists Union.

Heide-Jørgensen, M. P. (1994) Distribution, exploitation and population status of white whales (Delphinapterus leucas) and narwhals (Monodon monoceros) in West Greenland. In 
E. W. Born, R. Dietz and R. R. Reeves, eds. Studies of white whales (Delphinapterus leucas) and narwhals (Monodon monoceros) in Greenland and adjacent waters. Meddelelser om Grønland, Biosci. 39.

Heide-Jørgensen, M. P. and Acquarone, M. (2002) Size and trends of bowhead whale, beluga and narwhal stocks wintering off West Greenland. In M. P. Heide-Jørgensen and $\varnothing$. Wiig, eds. Belugas in the North Atlantic and Russian Arctic. NAMCO Scientific Publications 4.

Heide-Jørgensen, M. P. and Reeves, R. R. (1996) Evidence of a decline in beluga, Delphinapterus leucas, abundance off West Greenland. ICES J. Mar. Sci. 53: 61-72.

Heide-Jørgensen, M. P., Lassen, H., Teilmann, J. and Davis, R. A. (1993) An index of the relative abundance of wintering belugas, Delphinapterus leucas, and narwhals, Monodon monoceros, off West Greenland. Can. J. Fish. Aq. Sci. 50: 2323-2335.

Heide-Jørgensen, M. P., Acquarone, M. and Merkel, F. R. (1999) Flytællinger af fugle og havpattedyr i Vestgrønland 1998. Pinngortitaleriffik, Grønlands Naturinstitut, teknisk rapport 24 .

Heide-Jørgensen, M. P., Laidre, K. L., Wiig, Ø., Jensen, M. V., Dueck, L., Maiers, L. D., Schmidt, H. C. and Hobbs, R. C. (2003) From Greenland to Canada in ten days: tracks of Bowhead Whales, Balaena mysticetus, across Baffin Bay. Arctic 56: 21-31.

Hjort, C. (1976) An observation of Ivory Gull Pagophila eburnea migration along the East Greenland current Dansk Ornithol. Forenings Tidsskr. 70: 72-73.

Horsted, S. A. (2000) A review of the cod fisheries at Greenland, 1910-1995. J. Northwest Atlantic Fish. Sci. 28 (special issue): 1-112.

Huettmann, F. and Diamond, A. W. (2000) Seabird migration in the Canadian northwest Atlantic Ocean: moulting locations and movement patterns of immature birds. Can. J. Zool. 78: 624-647.

Kampp, K. (1988) Migration and winter ranges of Brünnich's Guillemots Uria lomvia breeding or occurring in Greenland. Dansk Ornithol. Forenings Tidsskr. 83: 117-130.

Kampp, K. and Kristensen, R. M. (1980) Fugle på Disko - Vestgrønland. Unpublished report.

Kampp, K., Nettleship, D. N. and Evans, G. H. (1994) Thick-billed murres of Greenland: status and prospects. In D. N. Nettleship, J. Burger and M. Gochfeld, eds. Seabirds on islands: threats, case-studies and action plans. Cambridge, U.K.: BirdLife International. Conservation series 1 .

Kapel, F. O. (1979) Exploitation of large whales in West Greenland in the twentieth century. Rep. Int. Whaling Commission 29: 197-214.

Kapel, F. (1995) Feeding ecology of harp and hooded seal in the Davis Strait - Baffin Bay region. In A. S. Blix, L. Walløe and Ø. Ulltang, eds. Whales, seals and man. Developments in Marine Biology 4. New York: Elsevier.

Kapel, F. (1996) Recoveries in Greenland, 1949-94, of tagged or branded harp and hooded seals. NAFO Sci. Council Stud. 26: 87-99.

Kapel, O. and Petersen, R. (1982) Subsistence hunting - the Greenland case. Rep. Int. Whaling Commission 4 (special issue): 51-74.

Koski, W. R. and Davis, R. A. (1994) Distribution and numbers of narwhals (Monodon monoceros) in Baffin Day and Davis Strait. In E. W. Born, R. Dietz and R. R. Reeves, eds. Studies of white whales (Delphinapterus leucas) and narwhals (Monodon monoceros) in Greenland and adjacent waters. Meddelelser om Grønland, Biosci. 39.

Lyngs, P. (2003) Migration and winter ranges of birds in Greenland. Dansk Ornitol. Forenings Tidsskr. 97: 1-167.

Madsen, J. (1998a) Experimental refuges for migratory waterfowl in Danish wetlands. I. Baseline assessment of the disturbance effects of recreational activities. J. Appl. Ecol. 35: 386-397.

Madsen, J. (1998b) Experimental refuges for migratory waterfowl in Danish wetlands. II. Tests of hunting disturbance effects. J. Appl. Ecol. 35: 398-417. 
Madsen, J., Pihl, S. and Clausen, P. (1998) Establishing a reserve network for waterfowl in Denmark: a biological evaluation of needs and consequences. Biol. Conserv. 85: 241-255.

Martin-Jones, J. and O'Connor, S. (1999) Ecoregion conservation in the north. WWF Arctic Bull. 99/2: 10-11.

Meltofte, H. (2001) Unsustainable take of murres in Greenland. In CAFF (Conservation of Arctic Flora and Fauna) Arctic flora and fauna: status and conservation. Helsinki: Edita.

Merkel, F. R. (2002) Ederfugleoptællinger i Ilulissat, Ummannaq og Upernavik Kommuner, 1998-2001. Pinngortitaleriffik, Grønlands Naturinstitut, teknisk rapport 43.

Merkel, F. R., Mosbech, A., Boertmann, D. and Grøndahl, L. (2002) Winter seabird distribution and abundance off West Greenland, 1999. Polar Res. 21: 17-36.

Mosbech, A. (1997) Assessment of seabird vulnerability to oil spills in the eastern Davis Strait. In Proceedings of the Fifth International Conference on Effects of Oil on Wildlife, 3-6 November 1997, Monterey.

Mosbech, A. and Boertmann, D. (1999) Distribution and reaction to aerial surveys of post-breeding king eiders (Somateria spectabilis) in western Greenland. Arctic 52: 188-203.

Mosbech, A. and Johnson, S. (1999) Late winter distribution and abundance of seaassociated birds in Southwest Greenland, Davis Strait and southern Baffin Bay. Polar Res. 18:1-17.

Mosbech, A., Dietz, R., Boertmann, D. and Johansen, P. (1996) Oil exploration in the Fylla Area. National Environmental Research Institute, Technical Report 156.

Mosbech, A., Boertmann, D., Nymand, J., Riget, F. and Acquarone, M. (1998) The marine environment in Southwest Greenland. Biological resources, resource use and sensitivity to oil spill. National Environmental Research Institute, Technical Report 236.

Mosbech, A., Anthonsen, K. L., Blyth, A., Boertmann, D., Buch, E., Cake, D., Grøndahl, L., Hansen, K. Q., Kapel, H., Nielsen, S., Nielsen, N., Platen, F. v., Potter, S. and Rasch, M. (2000) Environmental oil spill sensitivity atlas for the West Greenland coastal zone. Ministry of Environment and Energy, The Danish Energy Agency. http://environmental-atlas. dmu.dk

Mosbech, A., Grøndahl, L., Merkel, F. M. and Flagstad, A. (2001) Satellitsporing af kongeederfugl i Vestgrønland. National Environmental Research Institute, Technical Report 381.

Namminersornerullutik Oqartussat (2000) Piniarneq 2001. Nuuk: Namminersornerullutik Oqartussat/Atuakkiorfik.

Namminersornerullutik Oqartussat (2002) Piniarneq 2003. Nuuk: Namminersornerullutik Oqartussat/Atuakkiorfik.

Nielsen, P. (1998) Ændringer i effektivitet, udnyttelse og afsætning de sidste 20-30 år. In K. Rydahl and I. Egede, eds. Seminar om de levende ressourcer. Nuuk: Pinngortitaleriffik, Grønlands Naturinstitut.

Nygård, T., Larsen, B. H., Follestad, A. and Strann, K.-B. (1988) Numbers and distribution of wintering waterfowl in Norway. Wildfowl 39: 164-176.

Oldenow, K. (1933) Fugleliv $i$ Grønland. Copenhagen: Det grønlandske selskabs aarsskrift 1932-33.

Orr, C. D. and Parsons, J. L. (1982) Ivory Gulls Pagophila eburnea and ice-edges in Davis Strait and the Labrador Sea. Can. Field-Nat. 96: 323-328.

Pars, T., Osler, M. and Bjerregaard, P. (2001) Contemporary use of traditional and imported food among Greenlandic inuit. Arctic 54: 22-31.

Pedersen, S. A. and Smidt, E. L. B. (2000) Zooplankton distribution and abundance in West Greenland waters 1950-1984. J. Northwest Atlantic Fish. Sci. 26: 45-102.

Petersen, A. (1998) İslenskir fuglar. Reykjavík: Vega-Helgafell.

Petersen, A. (2000) Válisti 2. Fuglar. Reykjavik: Náttúrufræðistofnun Íslands.

Petersen, H., Meltofte, H., Rysgaard, S., Rasch, M., Jonasson, S., Christensen, T. R., Friborg, T., Søgaard, H. and Pedersen, S. A. (2001) The Arctic. In A. M. K. Jørgensen, J. Fenger 
and K. Halsnæs, eds. Climate change research. Danish contributions. Danish Climate Centre, Danish Meteorological Institute.

Rätz, H.-J. (1999) Structure and changes of the demersal fish assemblage off Greenland, 1982-96. NAFO Sci. Council Stud. 32: 1-15.

Reeves, R. R. and Heide-Jørgensen, M. P. (1996) Recent status of bowhead whales, Balaena mysticetus, in the wintering grounds off West Greenland. Polar Res. 15: 115-125.

Renaud, W. E. and Bradstreet, M. S. W. (1980) Late winter distribution of Black Guillemots in northern Baffin Bay and the Canadian high Arctic. Can. Field-Nat. 94: 421-425.

Renaud, W. E. and McLaren, P. L. (1982) Ivory gull (Pagophila eburnea) distribution in late summer and autumn in eastern Lancaster Sound and Western Baffin Bay. Arctic 35: 141-148.

Salomonsen, F. (1949) Mergus serrator schiøleri nom. nov. Dansk Ornithol. Forenings Tidsskr. 43: 186.

Salomonsen, F. (1950) The Birds of Greenland. Copenhagen: Munksgaard.

Salomonsen, F. (1967) Fuglene på Grønland. Copenhagen: Rhodos.

Salomonsen, F. (1968) The moult migration. Wildfowl 19: 5-24.

Salomonsen, F. (1979a) Ornithological and ecological studies in S.W. Greenland $\left(59^{\circ} 46^{\prime}-\right.$ $62^{\circ} 27^{\prime}$ N. Lat.). Meddelelser om Grønland 204 (6).

Salomonsen, F. (1979b) Marine birds in the Danish monarchy and their conservation. In J. C. Bartonek and D. Nettleship, eds. Conservation of marine birds of northern North America. United States Department of the Interior Fish and Wildlife Service. Wildlife Research Report 11.

Smidt, E. (1979) Annual cycles of primary production and of zooplankton at Southwest Greenland. Meddelelser om Grønland Biosci. 1: 1-53.

Stern, H. L. and Heide-Jørgensen, M. P. (2003) Trends and variability of sea ice in Baffin bay and Davis Strait, 1953-2001. Polar Res. 22: 11-18.

Tasker, M. L., Jones, P. H., Dixon, T. and Blake, B. F. (1984) Counting seabirds at sea from ships - a review of methods employed and a suggestion for a standardized approach. Auk 101: 567-577.

Tull, C. E., Germain, P. and May, A. W. (1972) Mortality of Thick-billed Murres in the West Greenland salmon fishery. Nature 237: 42-44.

Valeur, H. H., Hansen, C., Hansen, K. Q., Rasmussen, L. and Thingvad, N. (1997) Physical environment of eastern Davis Strait and northeastern Labrador Sea. Danish Meteorological Institute Technical Report 97-9 (2 vols).

\section{DAVID BOERTMANN}

National Environmental Research Institute, Department of the Arctic Environment, P. O. Box 358, DK-40oo Roskilde, Denmark.

\section{PETER LYNGS}

Guldbergsgade 22, 5., DK-2200 Copenhagen N, Denmark.

FLEMMING RAVN MERKEL

Greenland Institute of Natural Resources, P. O. Box 570, DK-39oo Nuuk, Greenland.

\section{ANDERS MOSBECH}

National Environmental Research Institute, Department of the Arctic Environment, P. O. Box 358, DK-400o Roskilde, Denmark. 